\title{
Biosecurity, a policy dilemma for New Zealand
}

\author{
Mairi ${ }^{1}$ Jay $^{\mathrm{a} *}$ Munir Morad ${ }^{\mathrm{b}}$, Angela Bell ${ }^{\mathrm{c}}$ \\ ${ }^{a}$ Department of Geography, University of Waikato, Private Bag 3105, Hamilton, New \\ Zealand; \\ ${ }^{b}$ School of Earth Sciences and Geography, Kingston University, Kingston-Upon- \\ Thames, Surrey, UK; \\ ${ }^{c}$ Ruapehu District Council, Private Bag 1001, Taumaranui, New Zealand
}

\begin{abstract}
Protection of New Zealand's native biodiversity and its primary production both depend on biosecurity measures to prevent invasion by alien, or exotic, organisms. At the same time, New Zealand's dependence on trade and travel in an increasingly globalised world places growing strain on the nation's biosecurity systems. Invasion by exotic species has potential for catastrophic impacts on both native biodiversity and human economic and social well-being. New Zealand's biosecurity policies have been gradually evolving from a narrow focus on production pests to a broader awareness of multiple economic, social and ecological objectives. This paper is about the process of reconciling conflicting objectives for biosecurity, with New Zealand as a case study example.
\end{abstract}

Keywords: Biodiversity conservation; Biological invasion; Biosecurity; Environmental Policy.

\section{Introduction}

'Biodiversity' or 'biological diversity' is the variety of life in all its forms, levels and combinations, including ecosystem diversity, species diversity and genetic diversity (IUCN-UNEP-WWF, 1991:210). In the context of a particular country, such as New

\footnotetext{
* Corresponding author. Tel. +64 (7) 8562889 x 8834; Fax. +64 (7) 838 4633; Email: mairij@waikato.ac.nz
} 
Zealand, it normally refers to species and ecosystems that are purely or predominantly native (indigenous) in their composition.

Biological diversity within (and between) species and ecosystems is widely recognised as a prerequisite for global environmental resilience, as well as a source of critical goods and services for the human community (Mooney, Lubchenko, Dirzo and Sala, 1995). Conservation of native biodiversity has become recognised as an issue of world-wide importance, and has been attracting the increasing attention of social scientists ${ }^{2}$.

Biosecurity as it has been defined in a New Zealand context is protection from the risks posed by organisms to the economy, environment and people's health through exclusion, eradication and control (Biosecurity Council, 2000).

'Biological invasion' is a term used to describe the naturalisation and unintended spread of unwanted organisms in areas where they have not previously occurred naturally. The organisms include plants, animals, bacterial diseases, fungi, and other pathogens, and they move as part of the global trade and travel movement of goods and people. Not all invasive organisms are damaging, economically, ecologically, or otherwise. By far the majority of exotic organisms that become established in a new area remain localised or unproblematic (Richardson et al, 2000; Williams and West, 2000).

But in past few decades sufficient numbers have caused enough economic or ecological damage to give rise to widespread alarm. Ecologists and other scientists 
have expressed growing concern at the impact of biological invasives on native species and ecosystems, (Bright, 1998; Drake et al, 1989; Enserink, 1999; Kaiser, 1999; Mooney and Hobbs, 2000; Mack and Lonsdale, 2001; Schmitz and Simberloff, 1997; Simberloff and Schmitz, 1999; Williamson, 1996), and the IUCN has developed a Global Invasive Species Programme (IUCN, 2000)

Examples abound of the sometimes catastrophic consequences for native biological diversity of invasions by exotic species. American chestnut blight (Cryphonectria parasitica), introduced into North America from Asia in the late 1890s, spread through 91 million hectares of hardwood forest in eastern USA and caused the virtual extinction of the American chestnut within its natural range (von Broembsen, 1989). The fungus that causes Dutch elm disease (Ophiostoma ulmi), thought to have originated in eastern Asia, was introduced to Europe in the early 1900s, and subsequently to North America, has almost eliminated elms from their natural range. The catastrophic spread of rabbits in the drylands of Australia is a classic example of the detrimental impacts of biological invasion by a mammal. Introduced rats and other predatory mammals to islands such as Hawaii, New Zealand and islands of the West Indies have caused drastic population declines and even extinction of many species of land and sea birds (Brown, 1989). More recently, the introduction of Leidy's comb jellyfish (Mnemiopsis leidyi) into the Black Sea in 1982 has brought the collapse of the Black Sea fisheries (Bright, 1999; Green, 2000). According to Brown (1989:90), “there is abundant evidence that invading species . . . have directly caused or indirectly contributed to the extinction of native species and substantially changed the structure and dynamics of both natural and human-modified ecosystems.”

${ }^{2}$ For example, in the field of ecological economics, and in relation to development studies and the management of common 
As volumes of trade and travel have increased worldwide, the detrimental effects of species invasions have increased. Di Castri (1989:27) has proposed three major 'crises' of biological invasion in recent geological time, all related to human population movement and accompanying plants and animals associated with humans. They include a pre-historic wave linked to the introduction and spread of agriculture; a second period, around 1500AD when the barriers of the biogeographical realms were broken owing to new transportation systems; and "the third, at present, because of the breakdown of the previous 'scaling rules', with much more extended space available in a much shorter time”. Furthermore, scientists expect threats to native biodiversity to increase in future as a consequence of the global changes such as landuse change, degradation of habitat, global atmospheric change (and in particular, its influence on fire and extreme weather events) globalisation of economies, and the susceptibility of disturbed ecosystems to invasive species. (Baskin, 1998; Mooney and Hobbs, 2000)

Of equal concern has been the effect of weeds, pests and disease pathogens on commercial crops. According to Bright (2001), an estimate of agricultural losses by David Pimentel and colleagues at Cornell University concluded that biological invasives could be costing the US as much as $\$ 123$ billion annually, while residents of the southeastern Unites States are suffering the effects of the Formosan termite, which is estimated to be causing US\$1 billion a year in property damage. 
Biosecurity and biological invasion are not concepts that have received much attention from social scientists in recent years, despite the fact that the overwhelming majority of invasive species introductions have been human-caused. While there is a substantial literature on the distribution and ecological impacts of species invasions, there does not appear to be much analysis of the social and political elements of species spread and species invasions.

Since Carl Sauer, biogeographers have long studied the distribution of plants and animals, and the interactions of species with human society and culture, including the causes and consequences of species extinctions. Economists have considered the cost implications of species invasions, and have developed methods to assess the costs and benefits for decisions related to control of pests, weeds and quarantine measures. For example, Naylor (2000), has provided a model for assessing the economic impacts of biological invasion by exotic species. Zavaleta (2000) has provided estimates and compared the costs of leaving Tamarix invasion in the USA uncontrolled or imposing controls. She concludes that the cost of impacts of Tamarix invasion on water resources, and the subsequent impacts on agriculture, municipal water supplies, recreation and wildlife, outweigh the enormous cost of control measures. A growing number of political scientists, political economists, and sociologists have considered the implications for biosecurity and biosafety of trade liberalisation (for example, see NcNeely), and for the food security of native people. However, important issues for social scientists remain consideration of the social consequences of biological invasions (who are the winners and who are the losers from biological introductions); the socio-political dynamics of decision-making about responses to bio-invasions (who are the winners and losers of political measures to 
control or ignore species invasions), social impacts and costs of control measures or non-control; and the social and political dimensions of the "pathways" by which alien species move between and within countries. As a contribution to the social science analysis of biosecurity issues, this paper considers some conflicts and trade-offs that are inherent in deciding between biosecurity goals and how these are currently being approached in the case study example of New Zealand.

\section{New Zealand's native biodiversity and biosecurity experience}

As an island nation, New Zealand has experienced both advantages and disadvantages from its biological isolation. It has benefited from an agriculture that has remained relatively free of pest and diseases found elsewhere, and this relative lack of pests and diseases has helped primary production to remain highly competitive in global terms. Conversely, an evolutionary process that has involved isolation for 60 million years or more, has left native species and ecosystems particularly vulnerable to the effects of exotic species (Brown, 1989; Clout and Lowe, 2000).

As a consequence of the impacts of exotic species, New Zealand has experienced catastrophic losses to its native biodiversity. Almost all the exotic species that have colonised New Zealand have been deliberately introduced by people. First were the Polynesians, who arrived 700 to a thousand years ago, and were instrumental in the extinction of some 35 native birds, including the moa. Next came the Europeans from the $18^{\text {th }}$ century onwards. European colonisation involved an almost total replacement of lower and mid altitude native forest, grassland and wetlands with a suite of introduced agricultural and domesticated plants and animals from the northern hemisphere and elsewhere. Sixty eight percent of New Zealand's contemporary 
landscape is now occupied rural farm and forest, and urban roads, towns, and cities, (Taylor et al. 1997).

So great has been the destruction to native species that New Zealand's State of the Environment report in 1997 noted that since European settlement 16 land birds have become extinct, at least a dozen invertebrates, and possibly as many plants (Taylor et al. 1997: 9.30). In addition, about 1,000 of known native species (of an estimated 80,000) are considered threatened (Taylor et al., 1997:9.48).

People continue to introduce new plants and animal species on an almost daily basis, and many of these subsequently manage to establish themselves. Establishment of new plant species continues at an average of 4 per year (Clout and Lowe, 2000). According to Green (2000) there are now some 25,000 exotic vascular plants in New Zealand, the vast majority (75\%) brought in as garden plants. The number of naturalised exotic plants (2071) now exceeds the number of native vascular plants (2055) (Williams and West, 2000:426). Of the naturalised exotic plants, the Department of Conservation considers more than 240 of naturalised exotic plants are weeds that actually or potentially threaten the survival of nationally rare or endangered native plants (Green, 2000). Nearly all types of native plant communities have been affected, including subalpine, tussock grasslands, frostflats, herbfields, montaine shrublands, freshwater wetlands and a full range of forest types (Green, 2000) . 
The impacts of biological invasions have been equally severe (although less well recognised) in New Zealand's marine areas. Exotic marine plants have been introduced to coastal waters by ships ballast and hull fouling (Green, 2000).

In the words of a publication by the Department of Conservation, "Introduced invasive species pose the single largest threat to the survival of many of New Zealand's threatened species and ecosystems. Better assessment and management of the biosecurity risks to native flora and fauna is needed if we are to arrest the current decline of New Zealand's unique biodiversity." (D.o.C., 1999)

\section{Biosecurity and Economic Welfare}

New Zealand's economy depends substantially on production from farming, forestry fishing and tourism. Primary products, (meat, wool, dairy, horticulture, timber, and fish) account for fifty percent of New Zealand's exports (Statistics New Zealand, 2000:515). In addition, tourism, New Zealand's top foreign exchange earner (Statistics New Zealand, 2000:306) is heavily dependent on natural attractions of the countryside.

At the same time as the destruction and erosion of native biodiversity, the country's economy has benefited greatly from a lack of pests, weeds and diseases commonly found elsewhere. For example, New Zealand has never experienced an outbreak of Foot-and-Mouth disease, and is free of such devastating diseases as avian influenza or Newcastle's disease (both of which attack poultry). 
Nevertheless, despite, or perhaps because of, the comparative advantages that primary production has enjoyed from a relative lack of pests, weeds and diseases, New Zealand primary producers are well aware of the threats posed by the introduction of unwanted organisms. Weeds such as ragwort (Senecio jacobaea), gorse (Ulex europaeus), blackberry (Rubus fruticosus agg.), argentine pampus grass (Cortaderai jubata and Cortaderia selloana), nodding thistle (Carduus nutans), and Hieracium, and of diseases such as Bovine Tb, have involved significant losses in productivity, or required major costs to control. The impact of exotic pests, weeds and diseases on the economy has been estimated at about1\% of Gross Domestic Product per year, plus intangibles (Bertram, 1999).

\section{Threats to New Zealand's biosecurity}

New Zealand's economic dependence on trade and travel, increasing volumes of trade and travel, and the increasingly globalised nature of trade and travel, have all increased the threat to native biodiversity and to human health and economic welfare from unintended bio-invasions. As the following tables show, not only has New Zealand experienced astonishing increases in the volume of trade in recent years, but the pattern of trade has changed drastically. Countries that were once outside New Zealand's trading sphere are now major sources of goods, creating new pathways for exotic organisms to enter the country.

\section{Insert Table 1 here}

Table 1 gives the weight of cargo unloaded at New Zealand seaports and airports between 1994 to 1999 . It shows that, overall, the weight of cargo increased 22\% in 
six years, with the vast bulk of the change coming from sea cargo (Statistics New Zealand, 2000:537).

From a surveillance viewpoint, the increases represent a major increase in the workload of the border control services. And a particularly worrying aspect of the increase is the number of container cargos. The number of containers is estimated to have increased in the region of 114\% between 1994 and 1999, from about 175,000 to about 375,000 (Budd and Arts, 2000:26). Only a proportion of these containers are opened for inspection by the quarantine authorities. Containers may carry bioinvaders both on the outside (e.g. attached to mud and dirt) and on the inside. They may be transported inland for miles before being unloaded.

\section{Insert Table 2}

Table 2 shows the rapid change in the structure of trade that New Zealand experienced between 1989 and 1999. It shows an overall 94\% increase in the value of imported merchandise, with an 80\% growth of imports from the countries of Asia (ranging from 36\% for Taiwan, to 544 for Malaysia, and 775\% for China). Equally important was the growth in imports from "other countries” of $241 \%$. This diversification of imports from Asia and "other countries" puts an additional strain on the biosecurity system because it requires a wider spread of pre-border agreements and controls. China, Malaysia and Thailand are countries of a continental mainland, and thereby more subject to natural biological dispersal than an island such as New Zealanders. Exporters from these countries are likely to be less concerned about biosecurity than New Zealanders because their borders are ecologically less distinct. Furthermore, cultural differences of language and custom create barriers that make it 
difficult for officials from each country to understand the biosecurity issues of the other.

In addition to the increases in importation of goods, the number of international visitors to the country has increased enormously. Between 1994 and 1999, the number of passengers who arrived by international airport increased 58\% from approximately 2 million in 1994 to 3,166,741 (Budd and Arts, 2000:25).

During the year 2000 MAF Quarantine Service reported that 1.8 tonnes of seed were confiscated in 4500 seizures, 16 tonnes of fruit fly host material was taken from passengers, and there were 168 seizures of live animals, including dogs and live eggs. 8.5 tonnes of meat and poultry products were taken off passengers, a third of which was undeclared, and two thirds from countries with foot-and-mouth disease (Sutton, 2001).

An intermittent review of newspapers over three months by one of the authors noted the following newspaper reports of biosecurity breaches:

- Discovery of a nest of red fire ants at Auckland airport (NZH, 22/12/2001:A7).

- Spread of Argentine ants to from Auckland to Hamilton, Bay of Plenty, and to Nelson and Christchurch in the South Island (WT, 2/9/01). First discovered in Auckland in 1990, the ants now appear to be impossible to eradicate.

- Capture of a pet Taiwanese stag beetle in an Auckland city home (NZH, 20/12/01:A3) which had been illegally smuggled in for recreational purposes;

- On-going efforts to eradicate an invasion of painted apple moth found in the Auckland vicinity (NZH 28/11/01). First discovered in Auckland in 1999, the 
- Discovery of mycoplasma micoides (subspecies mycoides (large colony) in dairy calves (WT 21/12/2001). Normally a disease of goats that had not previously been noted in New Zealand, the pathogen appears to have jumped the species barrier into cows.

- Efforts to halt the spread of the southern saltmarsh mosquito (Aedes (Ochlerotatus) camptorhynchus), an introduced mosquito dangerous to human health (NZH, 14/9/01).

These newspaper excerpts reflect the powerful pressures on New Zealand's biosecurity system brought about by current volumes of international travel and trade.

\section{The Biosecurity Framework}

Perhaps because New Zealand is a small island nation which has experienced significant biosecurity threats and problems, the biosecurity system that has evolved is unusual in the degree to which it operates as a relatively integrated framework. It involves different levels of government (national and regional), different biosecurity operations (surveillance, border control, and pre- and post-border control) and different biosecurity objectives (control of economically significant pests and weeds, protection of native species and ecosystems, protection of health, and the like) all working with some degree of inter-relationship. The system currently comprises:

\footnotetext{
3 The Ministry of Agriculture and Fisheries recently raised the estimate of damage from the moth should it become established to between \$58 and \$356 million over the same 20 year period, and received Cabinet approval for \$90 million pest eradication campaign (NZH, 10/9/02).
} 
i) pre-border measures (e.g. agreements with other countries on disease reporting procedures, checks and treatments of imported goods in countries of origin);

ii) a border control system that aims to prevent the entry of unwanted organisms into the country (Note: It is a managed risk approach that aims to reduce the risk of imports to 'acceptable levels'.)

iii) a system of emergency response to pest and disease incursion, the ‘introduced disease and pest response’ system;

iv) a surveillance system responsible for detecting unwanted organisms that have entered the country;

v) and a system of regional and national pest management for pests and diseases that have become established or naturalised in New Zealand.

These different systems focus on different aspects of biosecurity and are administered by different organisations. The different agencies are linked by legislation (the Biosecurity Act 1993), by a Minister for Biosecurity, and a Biosecurity Council. The Biosecurity Council is a multi-stakeholder advisory body to the Minister, which includes representatives from relevant the government departments, regional councils, primary production interests, tourism, and environmental organisations.

In principle, a strength of the current system is that it recognises and provides for different biosecurity objectives (protection of human health, primary production, native biodiversity, and marine environments). The Minister for Biosecurity and Biosecurity Council provide a structure for leadership, integration and coordination of biosecurity functions across different government departments and different spatial 
levels of operation. In addition, the regional councils and the Ministry of Agriculture and Forestry have developed efficient and effective operational systems for their respective biosecurity responsibilities.

In the past, the biosecurity framework has been most successful in protecting the country from economically important organisms, and less successful in relation to protection of the natural environment. Within the past decade, the system has successfully eradicated or prevented the incursion of a number of economically significant pests and diseases, and controlled the spread of others. They include the horticultural pests citrus canker (Xanthomonas axonopodis pv. Citri), Queensland (Bactrocera tryoni) and Mediterranean (Ceratitis capitata) fruit fly , Xylella fastidiosa a disease of grape vines; the forestry pests Dutch elm disease (Ophiostoma ulm), gypsy moth (Lymantria dispar)) and white spotted tussock moth (Orgyia thyellina); and the livestock pests Brucella suis and Aujeszky’s disease of pigs, anthrax, Bovine brucellosis, Bovine Spongiform Encephalopathy (BSE), several significant diseases of poultry (eg Newcastles disease and avian influenza), and equine influenza, and equine infectious anaemia.

Although the emphasis on production pests is changing, as the ecological consequences to native ecosystems has become more widely recognised, the biosecurity framework has been unable to prevent the establishment of a number of ecologically significant organisms, including the Argentine ant, red imported fire ant, the scoliid wasp, and the highly invasive seaweed Undaria (Undaria pinnatifida). 
The strengths and weaknesses of the current system are a consequence of past and present political priorities, institutional divisions, the allocation of funds and functions between different agencies of government, and a scientific knowledge base that provides a relatively comprehensive understanding of commercially important weeds, pest and diseases. Until recently, these factors have served to favour the primary production sectors and neglect the agencies concerned with conservation of native biodiversity.

Politically significant, the Minister for Biosecurity is also the Minister of Agriculture and Forests and the Minister for Trade Negotiations. He is the New Zealand representative with the World Trade Organisation, responsible for promoting a New Zealand trade policy of freer world trade. To many environmentalists, the liberalisation of world trade is a major driver of bio-invasions, and one of the main reasons for increasing concern about future threats of bio-invasion (McNeely, 2000; Campbell, 2001).

The institutional and budgetary frameworks for biosecurity are equally weighted in favour of agricultural and forestry pests to the neglect of environmental pests. In the current financial year, 94.4\% of central government spending on biosecurity was allocated to the Ministry of Agriculture and Forestry; 3\% was allocated to the Department of Conservation; 2.4\% went to the Ministry of Fisheries; and .2\% went to the Ministry of Health.

As the key government department responsible for biosecurity functions, the Department of Agriculture and Forestry (MAF) is responsible for border control 
(MAF Quarantine Service), introduced pest and disease responses (such as emergency responses to an invasion of Foot-and-Mouth disease), and coordination of surveillance and post-border operational functions through a Biosecurity Authority. In practice, the Biosecurity Authority is the key government agency for coordinating biosecurity functions and is highly influential in determining the operational priorities of central government for expenditures at the national level. ${ }^{4}$ While the Biosecurity Authority has the strongest operational capacity for coordination of biosecurity functions, historically it has been strongly influenced by a production-focus that has meant a relative neglect of biodiversity concerns, most particularly, an almost total neglect of coastal and marine biosecurity. The professional background of top personnel in the Biosecurity Authority - veterinary science, animal health, production forestry, horticulture ( MAF 2002b) - make it likely that they will understand threats to primary production more easily than threats to native ecosystems. However, in fairness to the Biosecurity Authority, it should be noted that the Authority acknowledges the need for protection to all biosecurity sectors, and many of its pest and disease control operations are of equal importance for production and the native ecology. Its mission statement aims, “To protect New Zealand’s unique biodiversity and facilitate exports by managing risks to plant and animal health and animal welfare.” (MAF, 2002a).

Perhaps more important, in purely practical terms, the knowledge base that biosecurity officials have at their disposal tends to favour surveillance and control of organisms that are commercially important, if for no other reason than that we know the threats that such organisms pose. In contrast, knowledge of ecologically

\footnotetext{
${ }^{4}$ However, it should be noted that territorial regional authorities, using ratepayer funds rather than taxpayer funds, may have different priorities in accord with the differential regional impacts of different organisms.
} 
significant organisms (marine, freshwater, and terrestrial) is much less. Frequently, our knowledge of the damaging potential of a new organism comes from the wisdom of hindsight. As Williams and West point out, "although there have been several attempts to predict the attributes of species that are likely to be [environmentally] invasive, most efforts have been unsuccessful.” (2000:428).

\section{Political process and Possible solutions}

In 2001 the Minister for Biosecurity requested the preparation of a Biosecurity Strategy that will identify a policy framework for biosecurity decision making, suggest an appropriate level of protection against biosecurity risks, indicate areas of priority and responsibilities for action, and suggest an appropriate framework for legislation (BSDT, 2001). This proposed strategy has brought about a general soulsearching of objectives, processes and implementation methods for biosecurity. In particular, it has brought to the fore, the potential divisions of interest among different stakeholder groups. These stakeholders include environmentalists and conservationists concerned to promote the protection of native biodiversity (terrestrial and marine), a range of groups from the primary productionist sectors (pastoral agriculture, horticulture, forestry), tourism representatives, and those concerned with human health.

Although the past weight of operational prioritising has favoured economically significant organisms, growing awareness about the impacts of biological invaders on native species and ecosystems, and on human health, has prompted a wider consideration of biosecurity goals. The environmental viewpoint has grown in strength and promises to have an impact on the future objectives of the system. An 
indication of this change was the $\$ 9.8$ million over 5 years allocated by central government to coastal and marine biosecurity.

The importance of environmental/biodiversity objectives for biosecurity was presaged by the publication of the New Zealand Biodiversity Strategy published in February 2000. It stated as a desired outcome for 2020: "Biosecurity management is effectively coordinated between central and local government, private agencies and interested groups. Systems for managing pests affecting primary production and native biodiversity are coordinated .... Ecologically and socially acceptable mechanisms are in place to balance the benefits of new introduced species against potential risks to native species and ecosystems ...” (DoC, 2000:79). Because New Zealand is a signatory to the international Biodiversity Convention, this document has some stature.

A major report published by the Parliamentary Commissioner for the Environment (2000) provided a comprehensive analysis of New Zealand's biodiversity framework. It was highly critical of the operational weight placed on economic biosecurity objectives to the detriment of environmental objectives, and the almost total exclusion of marine biosecurity issues. It stated that New Zealand's biosecurity system needs a set of clearly articulated directions, "particularly in relation to native flora and fauna, biodiversity, and ecosystem and public health" (2000:7). The country's largest environmental group, Royal Forest and Bird Protection Society of New Zealand included a feature on the report in its "Conservation News" to members (2001). The Forest and Bird society is a highly influential organisation within New Zealand's environmental community, and news items such as the report receive wide exposure. 
The Parliamentary Commissioner's report is likely to have provided a strong base for input by environmental groups into the process of preparing the government's Biosecurity Strategy.

At the time of writing this article, submissions to the government's first-round call for submissions to its Biosecurity Strategy had closed. The submissions will be followed by a draft strategy and a further round of public submissions. Final strategy recommendations are expected at the end of 2002. It will become clearer over the next few months whether the increased involvement of environmentalists into the political machinery of government policy making on biosecurity will translate into policy objectives and priorities.

\section{Conclusion}

In conclusion, New Zealand as a small island nation is threatened ecologically and economically by the increasingly fast and globalised nature of international trade and travel. The rapid movement of people by air from continent to continent, movement of cargo by roll-on-roll-off container, and expulsion of ballast by ships, are some of the ways by which biological organisms move from country to country. While many of the organisms fail to survive in the places they land, a significant number manage to survive and naturalise in their new environment. They may come to pose a threat to native biodiversity, or human health and economic well-being in the host country.

Biodiversity loss has come to be recognised as a world-wide problem, with long-term detrimental consequences. This recognition has influenced the views and concerns of environmentalists in New Zealand, and their involvement in a government review of 
biosecurity issues and objectives. New Zealand's commitment to the international Biodiversity Convention has also reinforced concern with the biodiversity aspects of biosecurity. From an earlier biosecurity focus on economically significant pests, weeds and diseases, there has developed a wider concern with threats from bioinvasives for native plants, animals and ecosystems.

Unfortunately, protection for primary production does not always coincide with ecological protection of native species and ecosystems, and the New Zealand record of effective control of potentially dangerous invasives is heavily weighted in favour of primary production. By contrast, prevention and control mechanisms have been much less successful for organisms that threaten native species and ecosystems. The record of success and failure is a consequence of political and institutional priorities that have in the past, strongly favoured economically important pests over environmental pests.

Over the past decade there has been a growing awareness by environmentalists of the importance of biosecurity for native biodiversity, and in New Zealand this awareness has been expressed through involvement in a policy review process. While the process is not yet complete, it seems likely that a final outcome will reflect greater awareness of biodiversity issues by biosecurity officials, and heightened efforts by the environmental community to incorporate biodiversity objectives into the biosecurity framework.

\section{References}


Baskin, Y. 1998. Winners and Losers in a changing world. Bioscience. 48, (10), 788792.

Bertram, G. 1999. The impact of exotic pests on the New Zealand economy. In, Hackwell, K. and Bertram, G. Pests \& Weeds, A Blueprint for Action. Wellington, New Zealand: New Zealand Conservation Authority, pp. 45-71.

Biosecurity Council, 2000. Towards a Biosecurity Strategy for New Zealand. Wellington, New Zealand: Biosecurity Council.

Brown, J.H., 1989. Patterns, modes and extents of invasions by vertebrates. In Drake, J.A., Mooney, H.A., di Castri, F., Groves, R.H., Kruger, F.J., Rejmanek, M., and Williamson, M. (eds.) 1989. Biological Invasions A Global Perspective. Scientific committee on Problems of the Environment, SCOPE 37. Chichester, New York: John Wiley \& Sons, pp. 85 - 111.

BSDT (Biosecurity Strategy Development Team), 2001. Issues Paper: Developing a Biosecurity Strategy for New Zealand. Wellington, New Zealand: Biosecurity Strategy Development Team, Ministry of Agriculture and Forestry.

Bright, C., 2001. Biological Adversity, The hidden costs of trade and economic globalisation. Harvard International Review. 22(4), 24-28. 
Budd, K., and Arts, A-M. 2000. Review of biosecurity influences of the last decade. Unpublished report prepared for the Parliamentary Commissioner for the Environment, Wellington, New Zealand, July 2000.

Campbell, F.T., 2001 The science of risk assessment for phytosanitary regulation and the impact of changing trade regulations. Bioscience, 52(2),148-153.

Clout, M. N., and S.J. Lowe, 2000. Invasive species and environmental changes in New Zealand. In Mooney, H.A., Hobbs, R.J. (Eds.) Invasive Species in a Changing World. Washington, D.C.: Island Press, pp. 369-384.

Department of Conservation (D.o.C.), 1999. Biosecurity. A briefing for the New Minister for Food, Fibre, Biosecurity and Border Control, December 1999. Wellington, New Zealand: Department of Conservation

Di Castri, F., 1996. History of biological invasions with special emphasis on the Old World. In, Drake, J.A., Mooney, H.A., di Castri, F., Groves, R.H., Kruger, F.J., Rejmanek, M., and Williamson, M. (eds.) 1989. Biological Invasions A Global Perspective. Scientific committee on Problems of the Environment, SCOPE 37. Chichester, New York: John Wiley \& Sons, pp. 1-30.

Endres_A, Radke_V 2002. Land use, biodiversity, and sustainability. Journal of Economics [Austria], 1999, 70 (1),1-16

Enserink, M. 1999. Biological invaders sweep in. Science. 285 (5435), 1834 - 1836. 
Green, W., 2000. Biosecurity Threats to Indigenous Biodiversity in New Zealand, An Analysis of Key Issues and Future Options. Unpublished report to the Parliamentary Commissioner for the Environment. EcoLogic Conservation Consultants, Wellington, New Zealand, September 2000.

IUCN, UNEP, WWF, 1991: Caring for the Earth, A Strategy for Sustainable Living. Published in partnership by The World Conservation Union (IUCN), United Nations Environment Programme (UNEP) and WorldWide Fund For Nature (WWF), Gland, Switzerland.

IUCN, 2000: Global Invasive Species Programme, laying the groundwork to address invasive alien species in science, education, management and policy through collaborative international action. http://jasper.stanford.edu/gisp/home.htm $(14 / 09 / 02)$.

Kaiser, J., 1999. Stemming the tide of invading species. Science. 285(5435), 1836, 1838.

Mack, R.N., and Lonsdale, W.M., 2001. Humans as global plant dispersers: getting more than we bargained for. Bioscience. 51(2), 95-102.

McNeely, J.A., 2000. The future of alien invasive species: changing social views. In Mooney H.A. Hobbs, R.J. (Eds.), Invasive Species in a Changing World. Washington D.C.: Island Press, pp. $171-190$. 
MAF (Ministry of Agriculture and Fisheries, Biosecurity Authority) 2002a.

Overview of MAF Biosecurity Roles.

http://www.maf.govt.nz/biosecurity/about/roles.htm (13th September, 2002).

MAF (Ministry of Agriculture and Fisheries, Biosecurity Authority) 2002b. Who’s

Who - Key Staff. http://www.maf.govt.nz/biosecurity/about/key-staff.htm (13th

September, 2002).

Mooney, H.A., and Hobbs, R.J., 2000. Invasive Species in a Changing World. In

Mooney, H.A., Hobbs, R.J. (Eds.), Invasive Species in a Changing World.

Washington D.C: Island Press.

Mooney, H.A., J. Lubchenko, R. Dirzo and O.E. Sala, (1995) “Biodiversity and ecosystem functioning: basic principles”. In V.H. Heywood and R.T Watson (eds.), Global Biodiversity Assessment. Cambridge University Press for the United Nations Environment Programme. Cambridge.

Naylor, R.L, 2000. The economics of alien species invasions. In Mooney H.A.

Hobbs, R.J. (Eds.), Invasive Species in a Changing World. Washington D.C.: Island Press, pp. 241 - 260.

NZH (New Zealand Herald) 2001 \$1m boosts safeguards against feisty fire ant. Auckland, New Zealand: Weekend Herald, December 22-23, A7. 
NZH (New Zealand Herald), 2001. Specialists to tackle insect. Auckland, New Zealand: New Zealand Herald, 14/9/01:A7.

NZH (New Zealand Herald) 2002. \$90m last-ditch attempt to wipe out moth.

Auckland, New Zealand: New Zealand Herald.

http://www.nzherald.co.nz/storydisplay.cfm?thesection=news\&thesubsection=\&story

$\underline{\mathrm{ID}=2647128 \& \text { reportID=162576 }}(10 / 09 / 02)$.

New Zealand Government, 2001. Budget 2001 The Estimates of Appropriations for the Government of New Zealand for the Year Ending 30 June 2002. Wellington: Treasury, New Zealand Government.

Parliamentary Commissioner for the Environment, 2000. New Zealand Under Siege, A review of the management of biosecurity risks to the environment. Wellington, New Zealand: Office of the Parliamentary Commissioner for the Environment. http://www.pce.govt.nz/reports, 11th January, 2002.

Richardson, D. M., Pysek, P., Rejmanek, M., Barbour, M.G. , Panetta, F. D. , and West, C.J. 2000: Naturalization and invasion of alien plants: concepts and definitions. Diversity and Distributions. 6, 93-107.

Royal Forest and Bird Protection Society, 2001. New Zealand under siege from pests. Conservation News. No. 121, 2. 
Schmitz, D.C., and Simberloff, D. 1997. Biological invasions: a growing threat. Issues in Science and Technology. 13(4), 33-41.

Simberloff, D., Schmitz, D.C., 1999. An invasive species threat intensifies, U.S. steps up fight. Issues in Science and Technology. 15(3), 25 - 26.

Sutton, J., 2001. Speech to the Farm Forestry Association, 26/3/2001. Speech Archive, New Zealand Government Executive. http://www.executive.govt.nz/speech, $11^{\text {th }}$ January, 2002.

Statistics New Zealand, 1990. New Zealand Official Yearbook 1990. Auckland, New Zealand: Department of Statistics.

Statistics New Zealand, 2000. New Zealand Official Yearbook 2000. Auckland, New Zealand: David Bateman Ltd.

Taylor, R., Smith, I., Cochrane, P., Stephenson, B., Gibbs, N. 1997 . Chapter 8, The state of our land. In, The State of New Zealand's Environment 1997. Ministry for the Environment, Wellington: GP Publications, pp. 8.1-108.

von Broembsen, S.L., 1989 Invasions of Natural Ecosystems by Plant Pathogens. In Drake, J.A., Mooney, H.A., di Castri, F., Groves, R.H., Kruger, F.J., Rejmanek, M., and Williamson, M. (eds.). Biological Invasions A Global Perspective. Scientific committee on Problems of the Environment, SCOPE 37. Chichester, New York: John Wiley \& Sons, pp. $77-82$. 
WT (Waikato Times), 2001. Foreign ant pest now in Hamilton. Hamilton, New Zealand: Waikato Times, 2/9/01.

Willioms, J.A., West, C.J. 2000. Environmental weeds in Australia and New Zealand: issues and approaches to management. Austral Ecology, 25, 425-444.

Williamson, M., 1996. Biological Invasions. London: Chapman and Hall.

Zavaleta, E., 2000. Valuing ecosystem servies lost to Tamarix invasion in the United States. In Mooney H.A. Hobbs, R.J. (Eds.), Invasive Species in a Changing World. Washington D.C.: Island Press, pp. 261 - 300.

\section{Acknowledgements}

The writers would like to acknowledge the work of the reviewers who provided constructive and valuable suggestions. 
Table 1 Change in overseas cargo unloaded at New Zealand ports, 1994 and 1999

\begin{tabular}{|c|c|c|c|}
\hline & 1994 & 1999 & \%change \\
\hline \multicolumn{4}{|c|}{$\begin{array}{l}\text { Gross weight } \\
\text { (tonnes) }\end{array}$} \\
\hline Port of Whangarei & 3979596 & 4883705 & 23 \\
\hline Port of Auckland & 2393829 & 3070724 & 28 \\
\hline Port of Tauranga & 1016495 & 1022074 & 0.5 \\
\hline Port of Lyttelton & 577573 & 797606 & 38 \\
\hline Port of Bluff (Invercargill) & 790470 & 936250 & 18 \\
\hline Total seaports & 10328153 & 12171670 & 22 \\
\hline Auckland Airport & 65178 & 77260 & 18 \\
\hline Christchurch Airport & 8121 & 8728 & 7 \\
\hline All other airports & 5501 & 3971 & -28 \\
\hline Total airports & 78801 & 89959 & 14 \\
\hline Parcel post & 782 & 163 & -79 \\
\hline Total cargo unloaded & $10,407,736$ & $12,735,857$ & 22 \\
\hline
\end{tabular}

Source: Statistics New Zealand, 2000 p537 
Table 2 Change in the value of imports into New Zealand from the top ten countries of origin, 1989 to 1999

\begin{tabular}{|c|c|c|c|c|}
\hline & 1989 & & 1999 & \% Change \\
\hline & & \$million & & \\
\hline Australia & 2673 & & 5,367 & 101 \\
\hline USA & 2,067 & & 4,283 & 107 \\
\hline Japan & 3,338 & & 3,056 & 31 \\
\hline China & 141 & & 1,234 & 775 \\
\hline Germany & 540 & & 1,088 & 101 \\
\hline United Kingdom & 954 & & 1,066 & 12 \\
\hline Taiwan & 402 & & 547 & 36 \\
\hline Malaysia & 81.5 & & 525 & 544 \\
\hline Italy & 216 & & 518 & 140 \\
\hline Korea & 300 & & 504 & 68 \\
\hline Other countries & 1779 & & 6,061 & 241 \\
\hline Total & 12491.5 & & 24,249 & 94 \\
\hline
\end{tabular}

Source: Statistics New Zealand, 1990, p. 527; and 2000 p. 537. 